\title{
舶用変圧器の保守についての一考察
}

\section{A Research on the Conservation of the Marine Tansformers}

\section{羽田野 良二(海技専門学院)}

\begin{abstract}
It is considered one of the important functions for transformers to investigate the accident of marine transformers.

According to the results of my survey on Japanese vessels, I have found that 5 accidents break out every year, and the marine transformer oil will deteriorate in 4 or 8 years since it began to be used.

Therefore we should examine transformer oil, and overhaul the inner part of transformer once every four ycars. in that case, it is necessary to change transfarmer oil, when in bad condition.

And it is a good idea to examine oil colour once every year.
\end{abstract}

\section{1 ま がき}

衆知のようと最近船舶の交流化がさかんになつてきをした、すなわち総トン数4000トン以上の

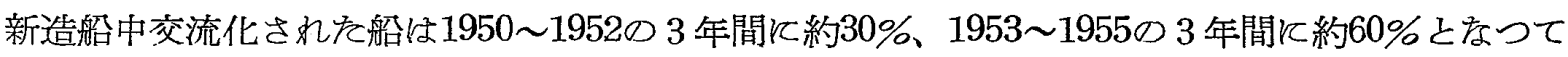

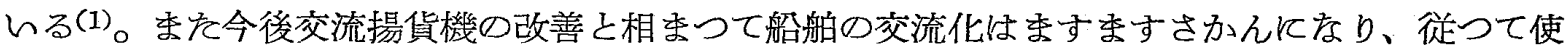
用される変圧器もそれだけ容量ならびね台数を増加することはあきらかである。

な持、一般商船に変圧器を使用し始めてから長きは 8 年を数えるにんそり、変圧器の事故 発生を耳にするようになつてきた。とのときにあたり従来あまり問題とされなかつた变圧器の保

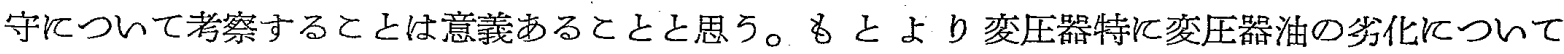
はこれまでに多くの研究報告(2)(3)があるが、船用のものにつんて特に取扱者の立場から論じられ をものはなんようである。幸い筆者は数多くの船船の御協力によつて変圧器事故なぞにつんての 貴重な資料を手にすることができ、また実際使用中の変圧器油につんて実験をおてなう機会を得 て、舶用変圧器の保守につんての一応の目安をえることがでさたので報告する次第である。

\section{2 交流化船の現況}

総トン数 4000 トン以上の交流化船につんて質問紙法によつて調查しを結果をまとめると次の通 りである。

(1) 電 力 状 況

船舶の交流化の当初は種及の事情から揚貨機は蒝気揚貨機を使用してんたるのが多かつた。 従つて使用電力量も此較的少をく発電機容量も小さんものが多かつた。また単穖運転を採用する ものが多かつたが、最近揚貨機の性能もよくなり全船電化のものが多くなり、使用電力量の増加

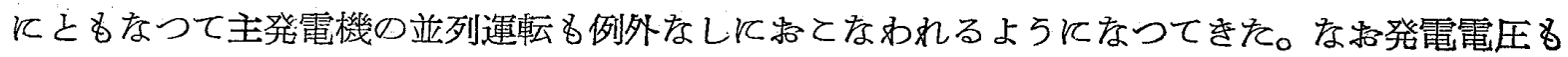


従来の 220〜230Vから次第に 440４50V 飞移行しつつあり、報告をらけを 1953１955の間に建 造されたもの30 隻中 18 隻をでが $450 \mathrm{~V}$ を採用しており年及増加の傾向にある。

(2) 装備変圧器の状況

第1.2.3 および 4 表に示すよ5に特筆すべをととは見当らなかつたが、一部の例外を除んて 変圧方法としては変圧器党使用していた。変圧器の種類としては単相の油大自冷式密閉型が主と して使用されていたが、最近乾式変圧器が船船にも使用され始めたてとは注目に值いするととで

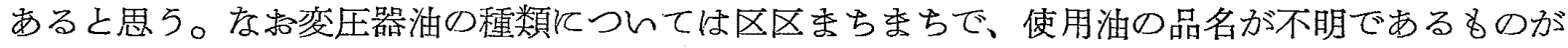
60\%近くあうをことには警かされた次第である。

第 1 表 変圧方法亡使用変圧器の種類

\begin{tabular}{|c|c|c|c|c|c|c|}
\hline & 查 & 項 & & $\%$ & 请 & 考 \\
\hline \multirow{2}{*}{ 変 } & \multirow{2}{*}{ 圧 方 法 } & 変 圧 器 使 & & 98 & & \\
\hline & & $\mathrm{M}-\mathrm{G}$ 使 & 用 & 2 & & \\
\hline \multirow{4}{*}{$\begin{array}{l}\text { 変 } \\
\text { 生 } \\
\text { 器 } \\
\text { の } \\
\text { 分 } \\
\text { 類 }\end{array}$} & \multirow{2}{*}{ 相 数ついて } & 単 相 変 圧 号 & & 100 & & \\
\hline & & 三 相 変 圧 呙 & & 19.6 & 単相と併用 & \\
\hline & \multirow{2}{*}{$\begin{array}{l}\text { 冷却方法 } \\
\text { について }\end{array}$} & 油入自冷 & 式 & 84.7 & & \\
\hline & & 乾式自冷 & 式 & 15.3 & & \\
\hline \multirow{2}{*}{\multicolumn{2}{|c|}{ 油保存器附かどうか }} & 附 $い \tau い$ & & 13.6 & & \\
\hline & & 附いていな & $w$ & 86.4 & & \\
\hline
\end{tabular}

第 2 表 変圧器容量 別隻数\%

\begin{tabular}{|rr|r|r|r|r|r|r|}
\hline 容 & 量 $\mathrm{KVA}$ & 10以下 & 11 20 & $21 \sim 30$ & $31 \sim 40$ & $41 \sim 50$ & 51 以上 \\
\hline 隻 & 数 $\%$ & 17.7 & 48.4 & 22.6 & 3.2 & 1.6 & 6.5 \\
\hline
\end{tabular}

第 3 表 変圧器使用経過年数别隻数 \%

\begin{tabular}{|l|r|r|r|r|r|r|}
\hline 使用経過年数 & 2 年以下 & $3 \sim 4$ & $5 \sim 6$ & $7 \sim 8$ & 9 年 以 \\
\hline 隻 & 40.4 & 38.5 & 6 & 7.7 & 11.5 & 1.9 \\
\hline
\end{tabular}

第4 表 使用変圧器油の種類 \%

\begin{tabular}{|c|c|c|c|c|c|c|}
\hline 絶縁油の種類 & $\begin{array}{l}\text { JIS } 1 \text { 号 } \\
\text { 相当油 }\end{array}$ & $\begin{array}{l}\text { JIS } 2 \text { 号 } \\
\text { 相 当油 }\end{array}$ & $\begin{array}{l}\text { JIS } 3 \text { 号 } \\
\text { 相当油 }\end{array}$ & 低圧絶縁油 & 高圧絶縁油 & $\begin{array}{l}\text { 不明 } \\
\text { 未記大を含む }\end{array}$ \\
\hline 数 $\%$ & 6.8 & 15.9 & 2.3 & 2.3 & 13.6 & 59.1 \\
\hline
\end{tabular}

(3) 変圧器の事故発生状泞

製作者も取扱者も変圧器とは事故は発生しないものというのが通り相場で、害際どの製作者

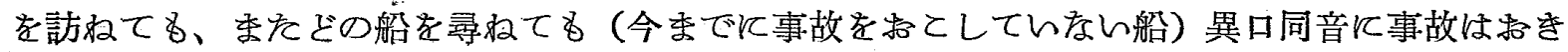


存んとんつている。しかし本調査の結果によると第 5 表に示すよらにか存りの事故発生率が認め

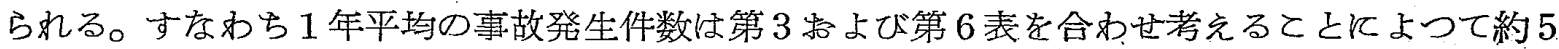
件に上つているととが推定される。

第 5 表 事故の分類亡その発生件数(\%)

\begin{tabular}{|c|c|c|c|c|c|c|c|c|c|c|}
\hline & 故 & の & 有 & 無 & 事 & 故 & が & $\supset$ & た & 事故がなかつた \\
\hline 隻 & & & & $\%$ & \multicolumn{5}{|c|}{28.9} & 71.1 \\
\hline 事 & 故 & の & 分 & 類 & $\begin{array}{l}\text { terminal } \\
\text { の 焼 椇 }\end{array}$ & $\begin{array}{l}\text { core } \\
\text { 熱 }\end{array}$ & $\begin{array}{l}\text { 発 } \\
\text { 損 }\end{array}$ & 巻線の焙損 & $\begin{array}{l}\text { 変圧器油の } \\
\text { 劣化(交換) }\end{array}$ & \\
\hline 件 & & & & $\%$ & 36.8 & & & 10.5 & 42.2 & \\
\hline
\end{tabular}

索事故の種類を分類してみると表示のように変圧器油の劣化が最も多く次に terminal の観 損事故と珎つている。

変压器油の劣化につんては水分や㕍芥の混入和よで温度の上昇をごが最も有害である(4)(5)(6)。 密閉型変压器を使用して必要な時以外は cover をど開放をさけ、できるだけ低温に保つように すれば淊の劣化は相当防止でをる筈である。油面計の破損したよらな晅合に簡単だからよんつて 上部の接続管を取除んて略式油面計を取付け事実上開放型とするよらなととは絶対にさけなけれ ばをらなんことである。

他の事故につんては完全な組立てと注意深ん点検と保守によつて殆んで防止できるものであ る。

変圧器油の劣化は完全に防止するととはでをないもので最近劣化防止のためと添加放を使用し をものにつんての研究報告(7):8)が挌てなわれているが、害際変压器に使用しを場合には多少の問

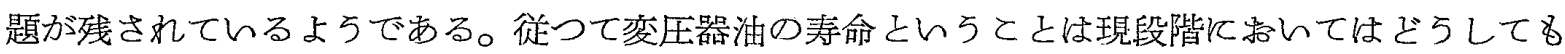
考えなければならない問題となつている。寿命をきめるものは何であり、またその程度はぼらあ

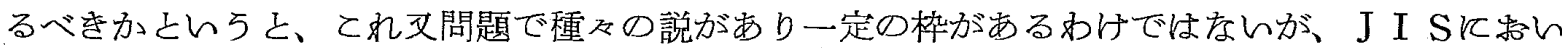
ては絶緣耐力 $30 \mathrm{KV}$ 以上、固有抵抗 $10^{14} \Omega$ 以上、全酸価 0.02 以下をごと規定しているが実際に 測定してみると絶縁耐力は实験 data に再現性がとばしく、てれのみによつて存命を断定するの は危険である。使用中の変圧器油飞つんては次に述べる実験結果からるわかるよらに劣化のため にこれらの規定值内にあるものは殆んどない、一般に使用中の油飞ついては絶緣耐力 $24 K V$ 、酸 俩0.5. 固有抵抗 $10^{13}$ をるて限度とする间が多いようである。

第 6 表は船令之事故の発生状洗を示した8ので、経過年数何年目にぞらんら事故が発生したか は不明であるが、とれによると変圧器油の劣化程度は 4 年目頃から要注意域にはいり8〜9年目 顷から危険域にはんるとんつてよんだるら。従つて適当を時期に試料油をとり絶縁耐力のみなら

第 6 表 船令亡事故の発生状況(件数)

\begin{tabular}{|c|c|c|c|c|c|c|c|c|c|c|}
\hline 事故の種別 & 1 & 2 & 3 & 4 & 5 & 6 & 7 & 8 & 9 & 謨 \\
\hline terminalの焼損 & 0 & 1 & 0 & 1 & 0 & 0 & 1 & 1 & 3 & 7 \\
\hline Coreの発熱焼損 & 0 & 0 & 0 & 0 & 0 & 0 & 0 & 0 & 2 & 2 \\
\hline 巻線 の焼損 & 0 & 0 & 0 & 0 & 0 & 0 & 0 & 0 & 2 & 2 \\
\hline $\begin{array}{l}\text { 変厓器油の劣化 } \\
\text { (交) }\end{array}$ & 0 & 0 & 0 & 2 & 0 & 2 & 0 & 2 & 2 & 8 \\
\hline 計 & 0 & 1 & 0 & 3 & 0 & 2 & 1 & 3 & 9 & 19 \\
\hline
\end{tabular}


ずJ I SK規定されている程度の試験をおてない各試験值より綜合的に良否を判定し不良の場合 は清浄まをは交換すべきである。

(4) 変圧器の保守点検状沉

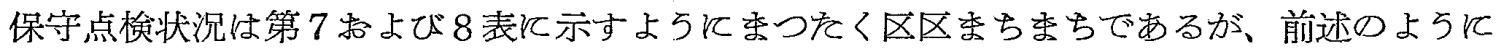

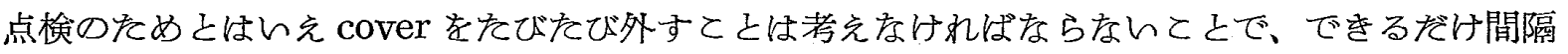

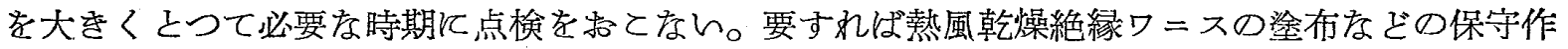
業を和てなつを方がよん。

第7表 内部点検実施状況

\begin{tabular}{|c|c|c|c|c|c|c|c|c|}
\hline $\begin{array}{l}\text { 内部点検をおこ } \\
\text { なつだうか }\end{array}$ & \multicolumn{7}{|c|}{ おこなつた事がある(予定を含む) } & おこなつた事がない \\
\hline 数 $(\%)$ & \multicolumn{7}{|c|}{48.1} & \multirow{3}{*}{$\begin{array}{c}51.9 \\
\text { (この中には内部点検の } \\
\text { 必要を認めないと回答さ } \\
\text { れたもの5.9\%を含む) }\end{array}$} \\
\hline 内部点検の期間 & 3 力月 & 6 力月 & 1 年 & 2 年 & 3 年 & 4 年 & $\begin{array}{l}\text { 䔬状を䜑 } \\
\text { めた時 }\end{array}$ & \\
\hline 数 $(\%)$ & 12.0 & 20.0 & 28.0 & 12.0 & 4.0 & 16.0 & 8.0 & \\
\hline
\end{tabular}

第 8 表 変医器油の試験実施状況

\begin{tabular}{|c|c|c|c|}
\hline 変圧器油試験実施の有無 & \multirow{2}{*}{\multicolumn{2}{|c|}{$\frac{\text { おこなつた }}{15.9}$}} & \multirow{2}{*}{$\frac{\text { おこなつた事がない }}{84.1}$} \\
\hline 隻 数 $(\%)$ & & & \\
\hline 同上試験 結 果 & 良 & $\begin{array}{l}\text { 不交換) } \\
\text { 变 }\end{array}$ & \\
\hline 数 $(\%)$ & 28.6 & 71.4 & \\
\hline
\end{tabular}

\section{3 実 験 結 果}

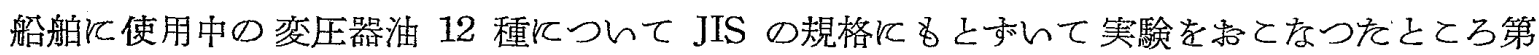
9 表飞示すような成績を得を。

これそよるとH丸こM丸以外の各船のdataは、(1)全酸価が使用限界の 0.2 以上てなるとこれ 之固有抵抗值との間飞或る関係がある、すなわち全酸価の増大は大体固有抵抗の低下となる(9) と ん5研究結果に大体一致しているとと、(2)絶縁耐力試験の結果のみによつて絶縁油の良否判定を

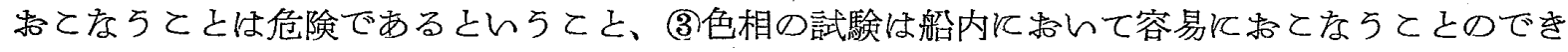

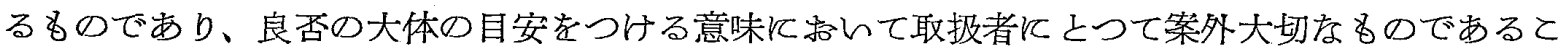
となどがわかつた。

な使用年数别に検討してみると絶縁耐力值の外飞大体 $3 \sim 4$ 年以上使用したものが使用限度

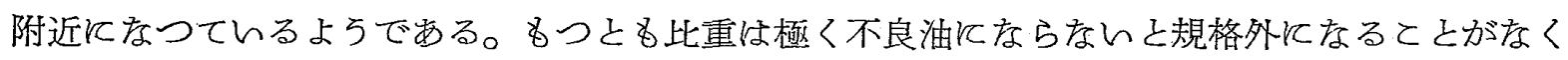
本実験結果においても大しを変化は認められなかつをが、使用年数亡共に次第に大をくなる傾向 そあるこ亡は認められた。

以上要約すると使用年数 $3 \sim 4$ 年目頃から変压器活の劣化程度は一般にんわれている使用限度 に達するものであるとんえよう。

\section{4 結 論}

主機関をはじめ数多くの補機類の運転保守の任にある船船乗組機関士や普通船員の手は非常に らすん、従つて可動部分もなく振動や衝撃音もをい変压器の保守点検仕どらかすると忘れられ勝 
第 9 表 実験結果(他の試験項目につんては余り変化がなんので省略しを)

\begin{tabular}{|c|c|c|c|c|c|c|c|c|}
\hline$\gamma$ & 試験項目 & 比重 & 全酸価 & 絶縁酎力 & 固有抵抗 & 色 相 & 備 & 䓔 \\
\hline 種 & 別 & $\left(15 / 4^{\circ} \mathrm{C}\right)$ & $\mathrm{mg} \mathrm{KOH}$ & $(\mathrm{KV})$ & $\left(\begin{array}{r}\Omega 2-\operatorname{cm} \\
50^{\circ} \mathrm{c}\end{array}\right)$ & $\left(\begin{array}{l}\text { オン} \\
\text { オン }\end{array}\right.$ & 使用年数 & そ の 他 \\
\hline JIS & 1 号 油 & 0.92 以下 & 0.02 以下 & 30以上 & $10^{14}$ 以上 & - & 新 油 & $\begin{array}{l}\text { 主として油入箁電器および } \\
\text { 油入ケーブル等に用いる }\end{array}$ \\
\hline 緣 & 2 号 油 & "I & "I & "I & 一 & - & "I & $\begin{array}{l}\text { 主として大容量の油入変厓 } \\
\text { 器および油入遮断器等に角 } \\
\text { いるもの }\end{array}$ \\
\hline $\begin{array}{l}\text { 腮 } \\
\text { 摫 } \\
\text { 格 }\end{array}$ & 3 号 油 & " & 0.05 以下 & "I & - & - & " & $\begin{array}{l}\text { 圭しして小容量の油入変压 } \\
\text { 器および油入遮断器等に用 } \\
\text { いるもの }\end{array}$ \\
\hline & A 丸 & 0.896 & 0.07 & 28.3 & $5.8 \times 10^{12}$ & $2 x / 2$ & & \\
\hline & B 丸 & 0.893 & 0.11 & 41.5 & $2.1 \times 10^{12}$ & $+2 x / 2$ & & \\
\hline 使 & 丸 & 0.882 & 0.36 & 29.9 & $8.4 \times 10^{11}$ & +3 & & $\begin{array}{l}\text { 缶室と背中合せの高温の } \\
\text { 場にあり }\end{array}$ \\
\hline 用 & D 丸 & 0.883 & 0.16 & 27.5 & $1.6 \times 10^{13}$ & -2 & & \\
\hline 中 & E 丸 & 0.895 & 0.68 & 32.3 & $7.9 \times 10^{11}$ & $-3 x / 2$ & & $\begin{array}{l}\text { タービン船 } \\
\text { 比較的高温の場所にあり }\end{array}$ \\
\hline$\infty$ & F 丸 & 0.873 & 0.72 & 42.0 & $5.9 \times 10^{11}$ & $+35 / 2$ & $3 \sim 4$ & \\
\hline & 丸 & 0.895 & 0.71 & - & - & & & 船側で陚験したデーター \\
\hline 変 & $\mathrm{H}$ & 0.886 & 0.11 & 38.5 & $4.1 \times 10^{11}$ & 2 & & $\begin{array}{l}\text { 冷凍機と並んだ比皎的低 } \\
\text { 温の場所にあり常時軽負 } \\
\text { 荷約 } 25 \%\end{array}$ \\
\hline 压 & 丸 & 0.903 & 0.82 & 28.2 & $1.4 \times 10^{12}$ & -5 & & \\
\hline 器 & 丸 & 0.902 &, 0.67 & 49.5 & $2.9 \times 10^{12}$ & $3 \pi / 2$ & $4 \sim 5$ & \\
\hline & K 丸 & 0.904 & 0.57 & 29.3 & $4.1 \times 10^{11}$ & $-45 / 2$ & & \\
\hline & 丸 & 0.897 & 0.67 & 47.2 & $1.3 \times 10^{12}$ & $3 \pi / 2$ & & $\begin{array}{l}\text { 漏油多く1年に全油量の } \\
\text { /6補給している }\end{array}$ \\
\hline & M 丸 & 0.897 & 0.15 & 29.0 & $6.9 \times 10^{11}$ & $4 \mathrm{I} / 2$ & 8 & \\
\hline
\end{tabular}

になつてんる。しかし前述のよ5に変圧器の事故発生数はかなりの数に上つてんる。てれは「変 压器には事故はなんるの」と安心しきつて油断をしてんるをめとも考光られる。

本調查研究の結果より見て、このような事故を未然防止するをめには日常の保守点検すなわ ち油面および温度上昇度の監視や異常ならなり等に注意する外、特に次の各項に気をくばるべを であると思う。

(1) 保守点検につんて

(1) 絶縁抵抗の測定はできるだけ多く行い結果を記録して参考にするとと。

(2) conservator 附のものは吸湿㶡の吸湿能力を時及調べて早目飞交換するてと。 
(3) 6 か月〜 1 年飞 1 度ぐらん色相を船内で調べるとと。

(4) 2 年〜 4 年に 1 度ぐらん尃門家に依頼して絶縁油の各種試験を祘こない、劣化程度に応 して新油と交換まをは清浄を依頼すること。

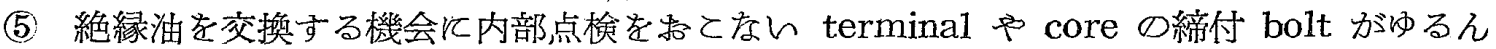

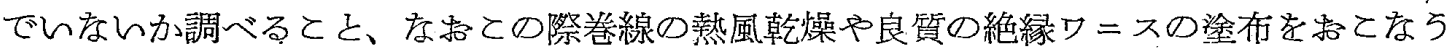
¿よh、

(6) cover や manhole door はでさるだけ開けなんとと。

(2) 艤装につんて

(1) 湿気の混入によつて絶緣油の絶縁耐力や固有抵抗が非常飞低下すること、また高温中反 使用されている各種絶縁物はその寿命が非常に短縮される(10) ことなどから考えて、その 据付位置は通風のよん低湿の場所を選定し火災の尔それのないとてろにするとと。

（2）保守点検が容易にできるようれ据付けること、見学をしれ殆んぞの船（約20数隻）の現 場が試料油を採るのに相当困難であるか、あるいは cover をはずさければ採取不可能な 状態であつそが、試料油が手軽に採れるよう飞据付けるべきである。

(3) 今後の見通し江つんて

現在装備されている変压器は開放型、conservator 附学よび密閉型なざ種及の型式を採用し てんるが近年 $\mathrm{B}$ 種やH種の絶縁材料を使用した電力用乾式変圧器の製作が工業化され船船にも使 用されだした。この乾式変圧器は不燃性非懪発性で油入変压器に竌いて心配されている火災の恐

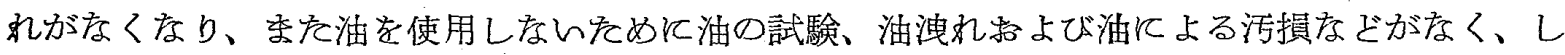

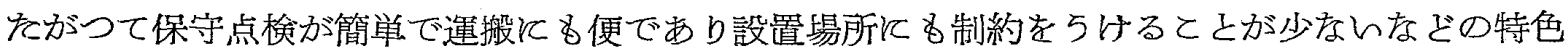
があるが一般に損失がやや大であり、洒格が油入変压器の 3 割〜 6 割増になつている。

以上述べをととを綜合すると、船船のように小容量の変圧器としては油入変压器では密閉式を 採用すべをであり、まを価格は高くなるが乾式変圧器が舶用としては最適のものと考えられる。

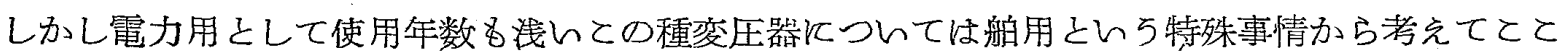
数年間は取扱者としての乗組機関士は研究的態度で保守点検にあたらなけれぱならないと思う。 以上舶用変压器の現状と保守につんての一試案を御報告申上げ海上第一線てて御活躍中の㫮様の ために些かでも役にたてばての上をい幸と存じます。

終りに本調查研究のために終始御留䈍を御指導を賜わつた旧丸善础油現松村石油株式会社研究

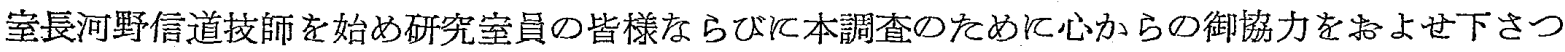
そ各船の機関長始め乗組機関士の方及飞深甚の謝意を表します。

\section{参考文 献}

(1) 日本海運集会所編. 日本船舶明細書(1955～56)

(2) F.M.Clark \& E.A. Synder, ASTM. Proceeding. 586(1936)

(3) 村山, 日石技報, 35号(1951)

（4）例えば，高木利夫著, 絶緑油の再生法

(5) Spath, Arch. f. Elektrot., 12 331(1923)

(6). 鳥山, 電気学会雑誌, 474 号 $70($ 昭, 3)

(7) 山田, 電気試験所研究報告, 352(昭, 8)

(8) A, S, Morrow, Iron and Steel Engineer, May(1953)

（9）例えば，寺瀬斉著，絶縁劣化検出の実際

(10) 白井, 三菱電機, 29(1955) 